Hegedűs Ernő ${ }^{1}$

\title{
KÉTSZÁZ ÉVE SZÜLETETT GÖRGEY ARTÚR ALTÁBORNAGY, A HADVEZÉR, HADERŐSZERVEZŐ, KATONAI-MÚSZAKI SZAKEMBER ÉS VEGYÉSZKUTATÓ, A 170 ÉVES HONVÉDSÉG EGYIK ALAPÍTÓJA
}

\author{
I. rész \\ DOI: $10.30583 / 2018 / 1-2 / 247$
}

\section{Összefoglalás}

Magyarország a 2018-as évben ünnepli Görgey Artúr (1818-1916), az 1848-1849-es magyar forradalom és szabadságharc föparancsnoka születésének 200. évfordulóját. Görgey, miután elhagyta a haderö kötelékét, a prágai egyetemen tanult kémiát 1845-1848 között. Diszszertációját a kókuszolaj zsírsavaiból írta, és a bécsi Akadémiai Közlemények hasábjain publikálta le. Ezután Görgey hazája első hívó szavára ismét katonának állt.

Kulcsszavak: Magyar Honvédség, katonai vezető, hadtudomány, kémia, logisztika, 170 éves a Honvédség

\section{Abstract:}

This year 2018 has seen Hungary to celebrate the 200th anniversary of Artúr Görgey's birth (1818-1916), who was the commander of Hungarian Revolution and War of Independence in 1848-1849.

After leaving the army, he graduated from chemistry at the University of Prague in years 1845 through 1848. His dissertation on examination of fatty acids of cocoanut oil had been published in the Report of Vienna Academy of Sciences. Görgey had volunteered for the defence of his fatherland which has sent a first call for it.

Keywords: Hungarian Defence Forces, military leader, military science, chemistry, logistics, 170th anniversary of HDF

1 Dr. Hegedűs Ernő mérnök őrnagy, MH LK Kutatás-Fejlesztési, Tudományos és Szabványosítási Osztály/Nemzeti Közszolgálati Egyetem KMDI/National University of Public Service KMDI, E-mail: hegedus.erno@hm.gov.hu, Orcid azonosító: 0000-0001-8457-5044 


\section{Bevezetés}

A Magyar Honvédség - mint a szuverén magyar állam politikai érdekérvényesítését szolgáló reguláris haderő - létrejöttét az 1848-as forradalom és szabadságharc időszakához köti a magyar hadtörténetírás. Ez a megállapítás - néhány előzmény figyelembevételével (amelyek szerint magyar reguláris haderő-elemek már a Rákócziszabadságharc után megjelentek az osztrák császári haderőben, továbbá hogy a magyar nemesi felkelés szabályzatai és vezényleti nyelve már magyar volt) - indokoltan szolgálhat jelen tanulmány kiindulópontjaként. A tanulmány távolabbi célja, hogy - a nemzeti haderő fennállásának 170. évfordulóján - megvizsgálja a Magyar Honvédség alapításának körülményeit: mely katonai vezetök nevezhetők e szervezet alapítóinak abban az értelemben, hogy a kiképzetlen újonc vagy irreguláris nemzetör szervezetekböl kiképzett reguláris haderöt hoztak létre, illetve tevékenyen részt vettek annak hadfelszereléssel történő ellátásában. Több nagy formátumú magyar katonai vezető és hadmérnök - pl. Klapka György, Mészáros Lázár, Kiss Károly, Láhner György stb. - neve mellett itt elsősorban egy olyan komplex szakmai háttérrel rendelkező személyiség neve merül fel, aki egyaránt részt vett a haderő szervezésében és kiképzésében, hadfelszereléssel való ellátásában, illetve a hadak vezetésében is, és mindhárom területen jelentős eredményeket ért el. Ez a személy Görgey ${ }^{2}$ Artúr honvédtábornok.

Görgey Artúr (1818 - 1916) utász-, majd testőrtiszt, honvéd altábornagy, polgári képzettségét tekintve vegyészmérnök. Gyalog-, majd huszárezrednél teljesített szolgálatát követően az 1848 - 49-es forradalom és szabadságharc idején a tüzérfelszerelések beszerzéséért felelős szakember, majd a mozgó nemzetőrség egyik felállítója, később tábornok, a honvédsereg fővezére, végül hadügyminisztere. Hadtudományi területen több könyve, publikációja jelent meg, illetve a vegyészet területén is kiemelkedő eredményeket ért el, összességében több területen is sokat publikált. 1848 - 49-ben nem egészen egy évig állt az események középpontjában az akkor 31 esztendős Görgey, a hadvezér, a haderőszervező és a katonai-műszaki szakember. Az 1868-ban alapított Honvédség felállításakor katonai szakértőként vették igénybe szaktudását, így e szervezetnek is egyik alapítója, ezáltal kétszeresen is a Honvédség alapítójának tekinthetjük.

2 Nevének y-nal történő írásmódját a tanulmány 6. pontjában tárgyaljuk. 
Bár Görgey Artúr tábornok személyét - rendszerint aktuálpolitikai céloknak engedve - hosszú-hosszú évtizedeken keresztül méltatlanul kezelte a magyar közgondolkodás, napjainkra objektív történészek Kosáry Domokos, Katona Tamás, Hermann Róbert - munkája nyomán nyilvánvalóvá vált, hogy történelmünk egyik legnagyobb hadvezérét tisztelhetjük személyében. Görgey tábornok volt az, aki 1848ban a szabadságukért felkelők szervezetlen tömegéből szervezett, fegyelmezett, kiképzett hadsereget, a Magyar Honvédséget megalakította, létrehozta. A korabeli honvédség Európa-szerte csodálatot keltő hadműveleteit is Görgey Artúr honvéd tábornok irányította, vezényelte, nem egy csatában saját életét is kockáztatva. Győzelmet győzelemre halmozva érkezett el hadvezéri pályájának csúcspontjához, a tavaszi hadjárathoz, Buda várának 1849. május 21-i visszavételével. A Magyar Honvédség Görgey emlékének adózva választotta ezt a napot a Magyar Honvédelem Napjának. Az utász végzettségü Görgey nemzetközileg elismert kémikusként a laurinsav felfedezője volt (a kókuszolajban). ${ }^{3}$

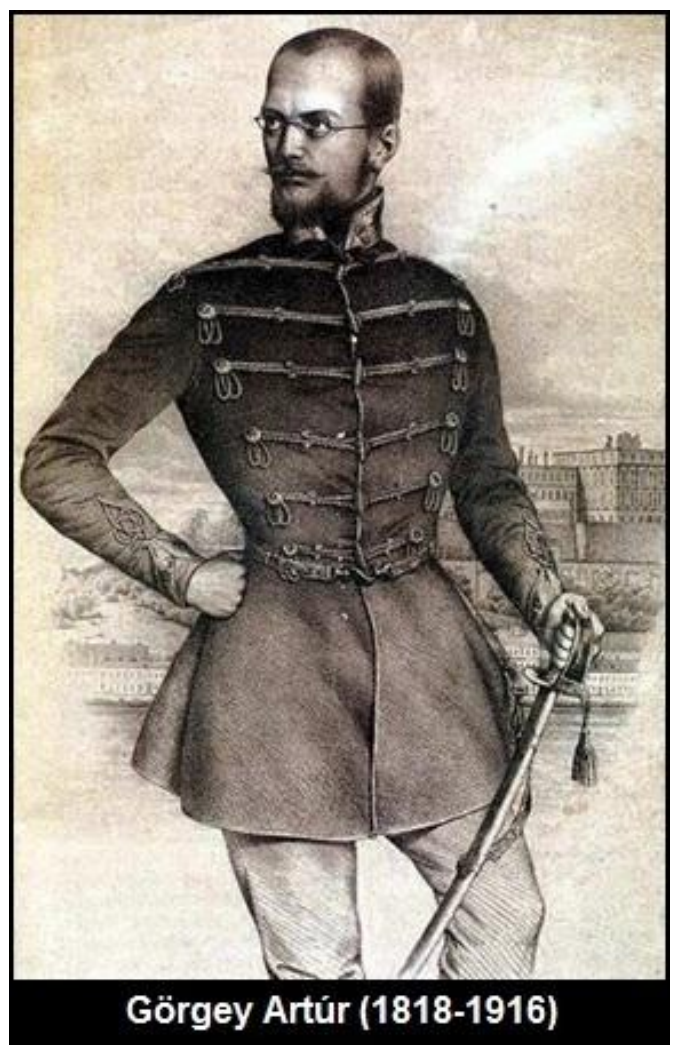

1. ábra. Korabeli rézkarc a tábornokról

3 Dodekánsav $(\mathrm{CH} 3(\mathrm{CH} 2) 10 \mathrm{COOH})$ 
Ha ma Görgeyre emlékeznek, külföldön is a kiváló hadvezérre gondolnak, kinek tavaszi hadjáratát, vagy mesteri visszavonulását a túlerőben lévő orosz csapatok között, például az amerikai West Pointi vagy a francia Saint Cyr-i katonai akadémiákon is tanítják. Azonban - Bonaparte Napóleonhoz hasonlóan (aki hadvezéri tevékenysége mellett különféle írásműveket is kibocsátott, illetve tollba mondta a CODE Napóleon polgári törvénykönyvet, továbbá maradandót alkotott Párizs várostervezésében és átépítésében, emellett különféle hidak és kikötők építésére is személyes hatást gyakorolt) - Görgey Artúr sem csak egyszerü katona volt. A tábornok vezérkari szintig vett részt katonai képzésben, emellett - az utász szakterülethez kötődően - a vegyészet és a kémia tudomány területén is jelentőset alkotott. Emellett hadiipar-szervezőként és haderőszervezőként is megállta a helyét, és a szabadságharcot követően számos hadtudományi jellegü írásművet is közreadott.

Jelen tanulmány közelebbi célja ilyen módon Görgey Artúr - mint a magyar haderő egyik alapítója - szakmai életútjának vizsgálata, a katonai vezetői tevékenység vizsgálata mellett kitérve tudományos, katonai-müszaki, haderőszervező tevékenységére, illetve a forradalmat követő, majd a két világháború közötti, továbbá az 1945 és az 1989 utáni megítélésének vizsgálatára.

\section{Tudományos tevékenysége}

\subsection{Kutatásai és publikációi kémikusként}

Görgey Artúr 1818. január 30-án született a felvidéki Toporcon, elszegényedett nemesi családban. Tanulmányait Késmárkon kezdte. Tanár szeretett volna lenni, de apja, Görgey György utasítására katonai pályára lépett. 1832 és 1836 között a tullni katonai utászakadémia hallgatója lett. Görgey „úgy vélte, hogy a jó hírű tullni katonai utásziskolában majd megismerkedik az őt érdeklő technikai és természettudományos ismeretekkel. E reményében nem is csalódott. A monarchiában ugyanis a müszaki tisztképzésnek hagyományai voltak; az utászkart például még III. Károly szervezte, megindította a bécsi mérnöki iskolát, a késöbbi hadmérnöki akadémiát, ahol többek közt Bolyai János is tanult. A hadmérnöki akadémia mellett kora legszínvonalasabb technikai képzése a Korneuburgban, majd az AlsóAusztriában, a Duna partján fekvő Tulln városában müködő cs. kir. utászkari hadapródiskolában folyt. Ebben a tanintézetben Görgey 
1832. novembertől 1836. szeptemberig egyévi előkészítő tanfolyamot és három rendes tanévet végzett." 4

Görgey 1836-ban a császári-királyi 60. gyalogezred hadapródja lett, majd 1845-ben felfüggesztette katonai szolgálatát, és - a család régi barátjára, Rösler Gusztáv bányatanácsosra hallgatva, ugyanakkor az utász szakterülethez is kötődően - vegyészetet és kémiát kezdett tanulni a prágai Károly Egyetemen. Görgey egyetemi tanulmányait 1845 októberében kezdte el Európa egyik legrégibb alapítású egyetemének kémia tanszékén. Önálló tudományos munkát is végzett, megoldotta a zsírsavhomológok elválasztását (sóik alkoholban való különböző oldékonysága révén). Kutatásának tudományos feladata volt, hogy eldöntse, vajon a kókuszdióolajban kapronsav és kaprilsav ${ }^{5}$ mellett előfordul-e kaprinsav ${ }^{6}$ is. A kókuszdió olajának zsírsavairól írott dolgozata 1848-ban két tudományos folyóiratban is megjelent. $E$ tanulmányával a kémikusok körében szakmai elismerést szerzett. Professzora tisztes ösztöndíjat és lakást biztosított neki.

Görgey Redtenbacher kémikus professzor tanítványa volt. Redtenbacher eredetileg a prágai egyetem professzora volt, itt volt hallgatója, majd tanársegéde Görgey Artúr. Az osztrák tudósnak, a bécsi és prágai egyetemek tanárának több magyar kapcsolata is volt. Görgey Artúr a Redtenbacher vezette tanszéken jelentős önálló munkát is végzett: új módszert fejlesztett ki a kókuszdió zsírsavainak elválasztására, és kimutatta, hogy a kókuszdióolajban a Liebig által felfedezett zsírsavakon kívül kaprinsav és laurinsav ${ }^{7}$ is található. (Tehát nem Görgey fedezte fel a laurinsavat, Ő a kókuszzsírban írta le először.) Ezzel a munkájával Görgey jelentős hírnevet szerzett azáltal, hogy az eredményeket a bécsi tudományos akadémia folyóirata és a Liebig által kiadott Annalen is közölte. Másik híres magyar tanítványa és később munkatársa volt Redtenbachernek, immár Bécsben, Than

4 Móra László: Görgey Artúr mint kémikus és haditechnikus. Technikatörténeti szemle, 20. évf. 1993. 139. o.

$5 \quad \mathrm{C}_{8} \mathrm{H}_{16} \mathrm{O}_{2}$. A kaprilsav egy szerves vegyület, szisztematikus neve oktánsav. 8 szénatomból álló telített karbonsav. Megtalálható glicerinészter formában különböző emlősök tejében, a kókuszolajban és a pálmaolajban is. (Wikipedia)

$6 \quad \mathrm{C}_{9} \mathrm{H}_{19} \mathrm{COOH}$. A zsírsavak közé tartozó szénvegyület, melynek gliceridje a vajban, a kókuszolajban, továbbá más növényi zsiradékban és az állati szervezetben is elöfordul. (http://www.kislexikon.hu)

7 Laurinsav (dodekánsav, laurát). $\mathrm{C} 11 \mathrm{H} 23-\mathrm{COOH}, \mathrm{CH} 3(\mathrm{CH} 2) 10 \mathrm{COOH}$ dodekánsav, telített karbonsav. (www.vilaglex.hu/Kemia/Html/Laurisav_.htm) 
Károly."8 Mint Redtenbacher tanítványa, és a negyvennyolcas szabadságharc egykori tüzére, Than Károly később tanulmányt írt Görgey kémikusi tevékenységéről. ${ }^{9}$ Than Károly ebben leírta, hogy Redtenbacher professzor Görgeyröl a legnagyobb elismeréssel beszélt.

Az egyetemi tanulmányokkal együtt jártak a gyakorlati célú tanulmányutak, így 1846-ban a przibrami bányákat, kohókat, vasgyárakat kerestek fel, egy év múlva pedig mezögazdasági mintaüzembe látogattak. $^{10}$

Görgey jól végezte tanulmányait, így a lembergi egyetem tanársegédjévé szerették volna kinevezni. Ö azonban Magyarországon akart vegyészi képzettségének megfelelő egyetemi beosztást kapni. Kémiai tanulmányainak eredményeit a hazai mezőgazdaságban kívánta érvényesíteni. Hazatért, és szakdolgozatát („A kókuszolaj szilárd és folyékony zsírsavai”) már magyarországi birtokán, Toporcon írta.

Egy nagyobb kölcsönböl vegyszereket és laboratóriumi segédeszközöket rendelt, otthon is folytatta kísérleteit. Toporcon fejezte be dolgozatát, és küldte el 1848. május 21-én Redtenbacher professzornak, aki olyan jónak találta, hogy bemutatta a bécsi tudományos akadémián, és két szaklapban is gondoskodott publikálásáról. A munka harmadik kiadása llosvay Lajos fordításában a Magyar Kémiai Folyóirat 1907. évfolyamában látott napvilágot.

Ez több kémiai szaklapban is megjelent. Megpályázta a müegyetemi kémiai tanszék átmenetileg megüresedett tanszékvezetői pozícióját. Professzori kinevezésére azonban a forradalom kitörése és a katonai pálya folytatása miatt végül nem került sor. (Ugyanakkor a szabadságharc bukása után még csaknem hetven évig figyelemmel kísérte a kémia fejlődését, de politikai üldöztetése miatt nem válhatott újra e tudomány aktív müvelőjévé.) Kutatási adatait később felhasználták, és minden nagyobb összefoglaló kémiai szakmunkában is megjelentették. 1907-ben Görgey dolgozatát magyarul is közreadták. Ő volt az első magyar kémikus, aki nemzetközi ismertségre tett szert.

8 Vámos Éva Katalin: Természettudósok három generációja Magyarországon, 1849-1918 Technikatörténeti szemle 2005. évi 6. sz. 27. évf. 220. o.

9 Than Károly: Egy magyar hadvezér mint chemikus. Budapesti Szemle 1893. évi 3. sz. Vol. 74. No. 197. pp. 161-180.

10 Móra László: Katonai sikereit elősegítették kémiai tanulmányai - 175 éve született Görgey Artúr. Magyar Tudomány, 1993. évi VIII. évfolyam 11. szám 2004. november. 
Magyar kémikus tudósként első ízben Ő publikált külföldi folyóiratban. A hivatkozásainak száma referált folyóiratokban elérte a hatot.

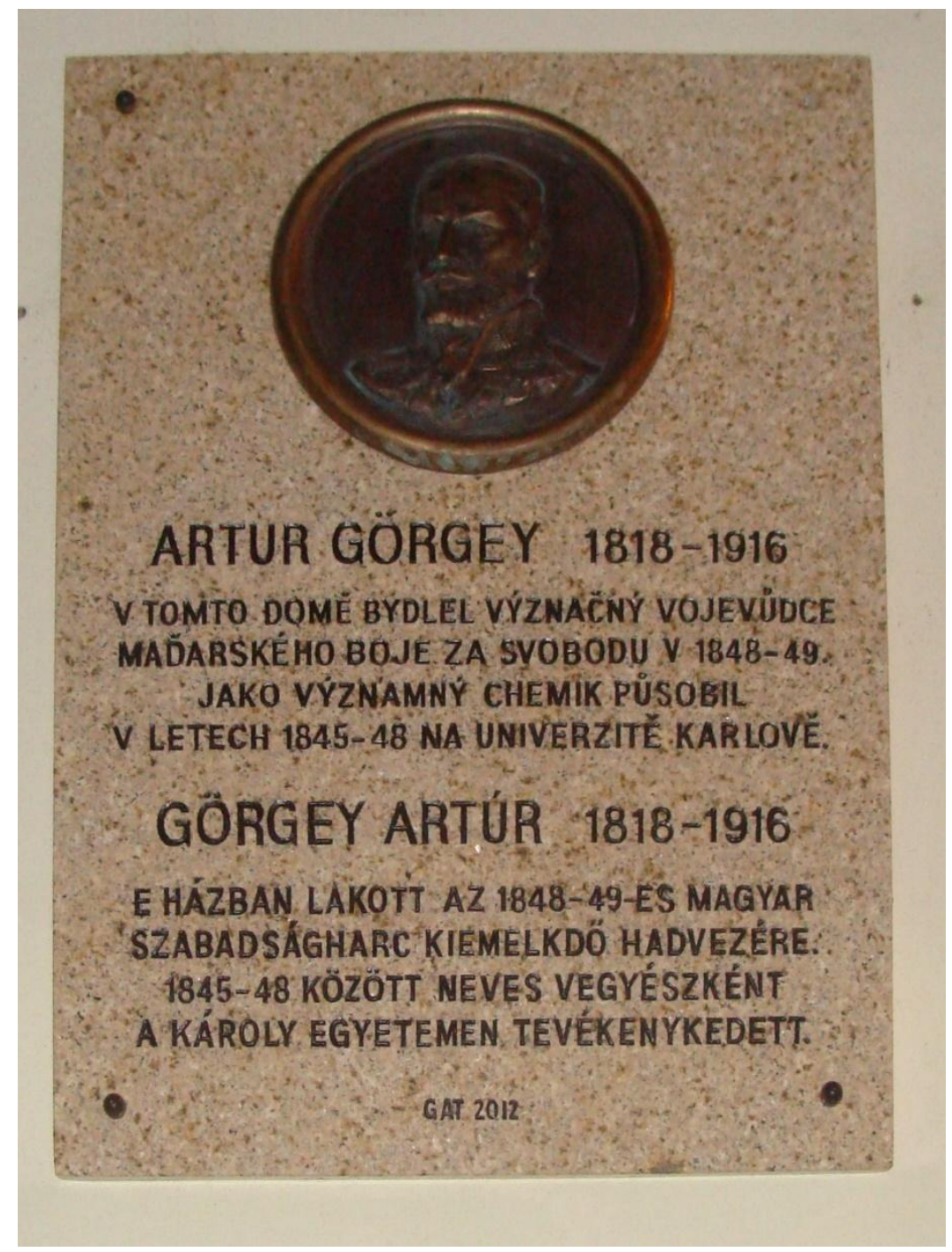

2. számú ábra. Emléktáblája a prágai egyetemen. 2012 tavaszán Prágában, a Kožná utca 8. sz. ház falán elhelyezték emléktábláját, a

Prágában diákként és tanárként töltött éveinek emlékére

2.2. Hadtudományi ismereteinek bövülése a testörségi szolgálat során; tudományszervező tevékenysége

Görgey képzett kémikus volt, de kérdés, hogy mennyire volt képzett katona. 1837-ben előléptették hadnaggyá, majd a Magyar Nemes Testörséghez került. Olvasta a hadtudományi irodalmat, benne a há- 
rom legnevesebb katonai teoretikus és szakíró, Károly főherceg, Jomini és Clausewitz műveit. Hermann Róbert szerint: „Görgey egyike volt a magyar hadsereg legképzettebb tisztjeinek: a tullni utászkari iskolában müszaki, a magyar nemesi testörségben töltött évek során vezérkari képzettséget szerzett, hadapródként a gyalogos, huszártisztként a lovas szolgálat rejtelmeivel ismerkedett meg." $A$ testőrség egyfajta vezérkari akadémiaként funkcionált a korabeli haderőben. A bécsi udvarban megközelítőleg 1320 fö magyar nemes ifjú szolgált 1760 - 1848 között, általában öt évig a testőrség kötelékében. Díszőrséget álltak a palotában, lovas kíséretet adtak az uralkodóház tagjainak, illetve futárküldetést teljesítettek. A testörség díszelgő funkciója mellett rendkívül jelentős célkitüzés volt a korszerü katonai ismeretek müvelésének meghonosítása is, a testőrtisztek magasabb katonai kiképzésben is részesültek. Komoly követelmény volt a folyamatos képzésben való részvétel. Az oktatás katonai gyakorlatokból, matematikai, hadi tudományokból, viselkedés-, tánc-, nyelvismeretekből állt. Görgey 1837 szeptemberében kerül a testörséghez. Itt az említettek szerint a vezérkari képzéshez hasonló oktatásban részesült. Amikor letelt a testörszolgálat ideje, Görgeyt a Nádor-huszárezredhez vezényelték. 1842-től itt szolgált főhadnagyi rendfokozatban.

Az 1848-as szabadságharc kitörésekor a Magyar Nemesi Testörség testőreinek többsége átállt a honvédseregbe, mint ahogy honvéd ruhát öltöttek jó néhányan a korábbi testörök közül is - például Görgey Artúr és Klapka György, akiknek felívelő forradalmi tiszti karrierjében jelentős szerepet játszott a korábban testőrségnél kapott vezérkari képzés.

1849-ben Görgey tábornok hadügyminiszterként is kapcsolatba került a katonai felsőoktatás területével. „Június 14-én ... Görgey Artúr hadügyminiszter ... ha nem is a tudományegyetem hadi tanfolyama megindítására, de a Magyar Hadi Főtanoda újbóli megnyitására melynek aligazgatója dr. Petzelt József honvéd alezredes, egyetemi tanár volt - több intézkedést adott ki, ám a tanítás a hadi események kedvezőtlen alakulása miatt már nem kezdődött el."12

11 Hermann Róbert: 1848-1849. A magyar szabadságharc hadtörténete. Budapest, 2001. 181. 0 .

12 Ács Tibor: Hadi tanfolyam a Bölcsészeti Karon és a Pesti Egyetemi Légió 18481849 - Fejezetek az Eötvös Loránd Tudományegyetem történetéböl 22. Budapest, 2001. 274. o. 
A szabadságharc bukása után Görgey számos hadtudományi munka szerzője volt. Megírta hadtudományi igénnyel bíró visszaemlékezéseit, két memorandumot írt 1867-ben az új honvédség felállításához, majd - Demár János álnéven - részletesen reagált Dembinszki emlékirataira 1875-ben a Budapesti Szemlében. ${ }^{13}$ Görgeynek ez a „nagyszabású ... munkája volt az első olyan szaktanulmány 1848-49 hadtörténetéröl, amely a modern történettudomány szabályainak megfelelően visszakereshető és pontos hivatkozásokkal (több, mint százzal) tárgyalja a témát ... Emlékiratainak megjelenését követően ebben a munkájában fejtette ki viszonylag részletesen a maga hadtudományi-stratégiai gondolatait." ${ }^{\text {14 }}$

\subsection{Logisztikai (anyagi vezérkari) ismeretei}

Logisztikai ${ }^{15}$ ismeretei elsősorban testőrségi szolgálata és az ott zajló vezérkari képzés során bővültek, emellett számos későbbi, a szabadságharc idejére datálható levelezése és ténykedése tanúsítja jártasságát e terület művelésében. A ma logisztikának nevezett anyagi vezérkari szolgálatot tanító tanárai is jó szakemberek voltak, mivel felkeltették érdeklődését a tárgy iránt, amely elősegítette tájékozódását az ezekben az évtizedekben virágzásnak induló logisztikai irodalomban. A logisztika szakemberei tanultak az előző háborúk tapasztalataiból, melyekben az anyagi ellátás, főleg az élelem- és takarmányellátás rendkívüli problémákat okozott. Különös élességgel világította meg a kérdést Napóleon 1812-ben végbement oroszországi hadjárata, mely elsősorban az élelemellátás megoldatlansága miatt katasztrófával végződött. A logisztika szakemberei e tapasztalatok alapján írásba foglalták és rendszerezték az egész ellátási rendszert, kezdve az élelem és takarmány beszerzésétől, a raktározáson át a szállításig. ${ }^{16}$ Görgey logisztikai szakismeretét a Kossuth Lajossal folytatott levélváltása bizonyítja. Az 1848. november 1-jén írt levele az általános vezérkari szolgálattal foglalkozik. A magasabbegységek

13 Görgey Artúr (Demár János álnéven): Dembinszki emlékiratai I. - V. rész. Budapesti Szemle, 1875.

14 Hermann Róbert (szerk.): Görgei Artúr válogatott írásai. Zrínyi Kiadó, Budapest, 2018. 37-38. o.

15

A logisztika kifejezést a napóleoni háborúk francia haderejében használták először (loger - hadtáp- illetve gazdásztiszt), így az 1848-as forradalom és szabadságharc idejére - többek között Jomini teoretikusi munkássága következtében is - már ismert volt.

16 Perjés Géza: Az élelemellátás kérdése Napóleon oroszországi hadjáratában. Századok, 1963.528-566. o.; Perjés Géza: Hadseregélelmezés, logisztika és stratégia a vasutak elterjedése előtti kétszáz esztendőben. Hadtörténelmi Közlemények, 1963. 1. sz. 216-281. o. 
szervezetének és ügymenetének ismeretében javasolja „a különböző katonai szolgálati ágak megszervezését”, kéri, hogy „térképek, rovatos táblák és más szükségletek" vásárlására pénzt utaljanak ki, egy nappal később pedig, hogy „a táborkarnál egy irattári hivatal állíttassék fel." ${ }^{\text {17 }}$ 1848. december 9-én kelt levelében „tábori intendatura", azaz logisztikai törzs felállítására tesz javaslatot. Így kezdi felterjesztését: „A feldunai hadsereg egyik legnagyobb hiánya a létszámi kimutatásban, s következőleg az élelmezésben is csaknem általában uralkodó rendetlenség." Megoldás az lenne, ha minden dandárhoz hadbiztost rendelnének. A menetek tervezését, az elszállásolást az intendáns végezze, de az ő dolga lenne az is, hogy a hadműveleti terület eltartóképességéről „alapos statisztikai adatokat szerezzen ... meg lévén mutatva tapasztalás által, hogy a legzseniálisabb tervek merő fellegvárak maradtak, ha azok készítésénél a statisztikai adatok számbavétele elhanyagoltatott." Majd pontokba foglalja az intendáns feladatait menetek tervezésénél. ${ }^{18}$

Görgey pályafutásának korai szakaszában olyan katonai szervezet parancsnoka is volt, amelynek müködésében jelentős szerepet szántak a korszak korszerű szállítási formáinak - a vasútnak és a gőzhajónak. Görgey 1848 augusztus 27-én kapta meg honvédőrnagyi kinevezését, és a tiszáninneni önkéntesen mozgó nemzetőrség parancsnokaként Szolnokra került. A nemzetör erők telepítésénél már figyelembe vették a Szolnok-Budapest, illetve a BudapestVác vasútvonal által adódó csapatszállitási lehetőségeket, illetve a folyami szállitás lehetőségeit is. ${ }^{19}$ Görgey szolnoki szervező munkája tíz napra és egy nemzetőr zászlóalj felállítására korlátozódott.

Görgey katonai vezetöi tevékenysége során is többször megnyilatkozott a haderő hadtápellátásának kérdéseivel kapcsolatban. 1849 februárjában Kossuth a politikailag hozzá közel álló, katonai végzettséggel nem rendelkező Henryk Dembińskit nevezte ki fövezérnek, aki Klapka seregét Miskolcra rendelte. Dembiński fővezérré való kinevezése a feldunai hadtest tisztikarában már február közepén ellenérzést szült. Dembiński és Görgey együttmüködési kísérlete hamar kudarcba fulladt. Görgey - egyebek mellett - nehezményezte, hogy az új fö-

17 Hermann Róbert (szerk.): Kossuth Lajos és Görgey Artúr levelezése, 18481849. Budapest, 2001. In: Millenniumi Magyar Történelem. Források. 73-74. 0. Hermann Róbert (szerk.): Kossuth Lajos és Görgey Artúr levelezése, 18481849. Budapest, 2001. In: Millenniumi Magyar Történelem. Források. 171-172. o.

19 Hermann Róbert: 1848-1849. A magyar szabadságharc hadtörténete. Budapest, 2001. 50. o. 
vezér az ő tudta nélkül rendelkezik a hadosztályparancsnokokkal, és hogy a hadsereg ellátásának központosítása fejetlenséghez vezet.

\section{Hadiipar-szervezői és fegyverzetianyag-ellátási tevékenysége a Honvédségben}

Görgeyt a március 15-ei események hírei komolyan foglalkoztatták. A kormány május 17-én, a honvédség megszervezésére kiadott felhívására nem sokkal később Pestre utazott, és jelentkezett a hadseregbe. Görgeyt, mint volt (huszár) föhadnagyot honvéd századosi ranggal osztották be a Győrött szerveződő 5. honvédzászlóaljba.

Az 1848 májusában létrejövő „nemzetőrség, valamint az első honvédzászlóaljak felállítása lényegében már az önálló magyar hadügy kezdetét jelenti" ${ }^{20} \mathrm{E}$ haderőszervezési folyamatban vett részt Görgey, amikor 1848 júliusában berendelték Batthyány Lajos miniszterelnök katonai irodájába (katonai) titkárnak, majd az Országos Nemzetőrségi Haditanács fegyverfelügyelői osztályának titkára lett. Konstantinápolyba, majd Szmirnába kellett utaznia, hogy fegyvereket vásároljon. A szabadságharc haderejében a lőfegyverek többsége gyutacsos, valamint „lőkupakos" (csappantyús) lőfegyverekből, kisebb részben kovás puskákból állott. A csappantyúk és gyutacsok Magyarországon nem készültek, ezeket a monarchia hadserege számára Ausztriában állították elő. A bécsújhelyi állami fegyvergyárban gyutacsot, valamint Prágában a Sellier és Bellot gyárban csappantyúkat gyártottak. Ezért Görgey előbb Bécsbe utazott, és a bécsújhelyi lőszergyárat tanulmányozta. Július 20-án Bécsújhelyre ment gyutacsokért, majd az osztrák hadügyminisztérium engedélyével intézte nagyobb mennyiségű készlet szállítását. A kívánt mennyiséget megszerezte a bécsújhelyi tüzérszertárból. 1848. július 21-én hivatali főnöke, Marziani György ezredes Görgeyt egymillió lőkupak (csappantyú) megrendelésére Prágába küldte, és ehhez egy hónapig érvényes útlevelet kapott. Prágában szerződést kötött a Sellier és Bellot céggel. Ezek szerint a Sellier és Bellot gyár köteles katonai lőkupakgyárat berendezni Budapesten. Ehhez a felállítandó gyár megbízott igazgatóját, művezetőjét és az alkalmazott munkásokat oktatják, bevezetik őket a szabványos hatszögű svájci formában előállítandó lőkupakok készítésének és töltésének, továbbá fényezésé-

20 Liptai Ervin (szerk.): Magyarország hadtörténete Zrínyi Kiadó, Budapest, 1985 I. köt. 456-457. o. 
nek részmunkálataiba. Az általuk birtokolt gyártási eljárásokat átadják. Mindezek fejében a m. kir. minisztérium évi 20 millió lőkupakot rendel, melyet a szállításkor kifizet.

Görgey útjáról visszatérve, 1848. július 18-án írt jelentésében részletesen beszámol a végzett munkáról, és tapasztalatai alapján javaslatot terjeszt elő a Budapesten létesülő gyártás megszervezésére. Görgey szakmailag, mint kísérletező vegyész, helyesen ismerte fel, hogy a gyártás kulcskérdése a préselt rézkupakokba kerülö robbantóanyag elkészítése és töltése, melyhez kellő ismerettel nálunk senki nem rendelkezett. (A veszélyes munkát később a pesti, majd a nagyváradi lőszergyárban külföldi vegyész, a francia Chateau végezte). Javaslatot tett az alkalmazandó technológiára is. A gyár vezetésére olyan vegyészt javasolt, akinek katonai képzettsége is van, feltehetöen magára célozva. 1848. augusztus 27-én Görgey javaslatot tett Batthyány miniszterelnöknek egy lökupak (kémiai müködésű csappantyú, gyutacs) gyár felállítására, hogy a magyar haderő tragikus lőszerhiányán segítsen. Elképzelését a hadügyminisztérium, majd Kossuth is jónak és megvalósítandónak tartotta. Ezért a lőkupakszállításról és a lőkupakgyár felállításáról 1848. augusztus 30-án kiadott rendeletében Kossuth pénzügyminiszter elfogadta a javasolt 20 millió lőkupak legyártásának határidejét és árát. Kossuth elégedett volt Görgey müködésével, erre vall, hogy Ludvigh János képviselőnek, későbbi kormánybiztosnak ez időben azt mondta, hogy a honvédtisztek között csak egy szervező tehetséget ismer, Görgey századost, belöle lesz majd a jövő hadügyminisztere.

A teljes körü meghatalmazás birtokában Görgey 1848. szept. 1-jén hosszú levelet intéz a prágai gyárosokhoz, és ebben a velük kötendő szerződés részleteit szabatosan újra megismétli: a gyár személyzetének betanítása, tapasztalatok átadása, évi 20 millió lőkupak szállítása, ennek rövid határidőn belüli megkezdése stb. Azt is kiköti, hogy a szállítmányok átvételénél próbákat vegyenek, a meg nem felelőket pedig a gyár költségére visszaküldik, továbbá az esedékes határidők elmulasztása esetén az érintett szállítás árát 10\%-kal csökkentik. A tervezett gyár azonban végül nem valósult meg. Marziani ezredest, akiről kiderült, hogy a fegyvergyártást lassítani igyekezett, leváltották, helyét Láhner György foglalta el, a későbbi aradi vértanúk egyik tábornoka. A hazai lőszergyártás a pesti Újépületben, továbbá a Pesti Hengermalom gépmühelyében és vidéken is megindult, illetve folytatódott. 


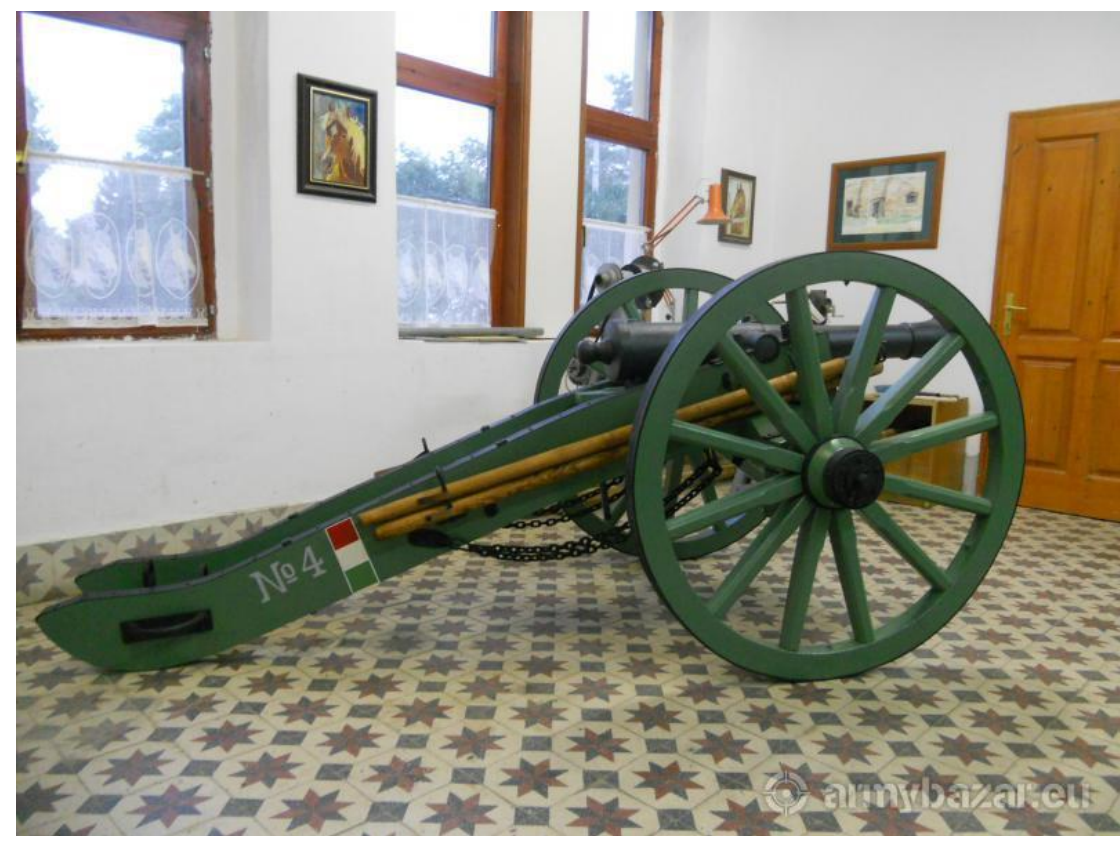

3. számú ábra. 3 fontos ágyú az 1848-as szabadságharcból

Habár - a kezdeti elképzelések szerint - Görgeyt tették volna meg a gyár igazgatójává, de azután katonai tapasztalatai miatt inkább a harcoló alakulatokhoz osztották be. 1848 szeptemberétől csapatparancsnoki beosztásokat látott el, azonban Görgey későbbi pályafutása során is részt vett a fegyverzeti anyagellátás kérdéseinek szervezésében, irányításában. A budai vár bevétele után Görgey utasította a tábori lőszerraktár parancsnokát, hogy állítson fel tüzér számvevőséget 6 tüzértiszt vezetésével, két munkásszázad erővel. A szervezet feladata a lőszerellátás felügyelete, illetve a raktározás és az ellátás megszervezése volt. A parancs szerint a lőszerfőraktárnak Pesten kellett települnie. ${ }^{21}$

1848 júniusában Görgey cikket jelentetett meg a honvédsereg egyenruházatának kérdéseiröl. ${ }^{22}$

Később hadügyminiszterként Görgey tábornok alárendeltségébe tartozott a szabadságharc magyar haderejének teljes ellátási rendszere.

21 Dr. Gáspár Tibor: A fegyver- és lőszerbiztosítás hazai történetének fontosabb tanulságai. PhD értekezés. ZMNE, 2008. 20. o.

22 Görgey Artúr: A honvédsereg egyenruhájáról. Budapest, 1848. június 5. In.: Hermann Róbert (szerk.): Görgei Artúr válogatott írásai. Zrínyi Kiadó, Budapest, 2018. 67. o. 


\section{Katonai tevékenysége}

\subsection{A mozgó nemzetörség parancsnokságától az ozorai győze- lemig és a schwehati helytállásig}

A Győrött szerveződő 5 . honvédzászlóaljban teljesített szolgálatát követően Szolnokon szolgált, mint a mozgó nemzetőrség parancsnoka. Szeptember 23-án Batthyány Szolnokról a Csepel-szigetre rendelte, hogy akadályozza meg Roth és Philippovich tábornokok csapatainak Jellasics seregével való egyesülését. Mint a Csepel-sziget katonai parancsnoka elfogatta a két Zichy testvért (Ödönt és Pált), akiknél Jellasicstól kapott menlevelet, illetve röpiratokat találtak, majd a rögtönítélő bíróság elnökeként Ödönt hazaárulás vádjával felakasztatta, Pál ügyét pedig átadta a polgári bíróságnak.

Jellasics 1848. szeptember 11-én történt támadása után szeptember 21-én magyar földre lépett a bán tartalék hadteste is (Rothhadtest). A 9000 fös hadtest feladata Jellasics jobb szárnyának védelme volt, és terv szerint Székesfehérvárnál egyesült volna a föerőkkel. A magyar hadvezetés tudott Roth közeledéséröl, és hadteste erőinek semlegesítésére 1848. október 2-án Móga János fővezér Perczel Mór nemzetőr ezredes alárendeltségében az Ercsinél gyülekező 5. hadoszlop parancsnokává nevezte ki Görgeyt, Perczel pedig az elöcsapat (2 gyalog- és 2 lovasszázad, 1 üteg) vezetésével bízta meg. A hadvezetés utasította Perczel Mór nemzetőr ezredest, hogy a saját és Görgey Artúr honvéd őrnagy parancsnoksága alatt álló nemzetőrökkel állja el a Székesfehérvárra dél felöl vezető utakat. Görgey október 4-én Tác helységig vonult, és megütközött két század horvát határőrrel, majd éjjel Soponyánál ismét szétkergette őket. Amikor elvágta visszavonulásuk útját, az ellenséges alakulat parancsnoka, Alois Haas százados ezer emberével letette a fegyvert. Amikor Philippovich tábornok értesült elővédjének sorsáról, megpróbált Ozora felé menekülni, és csapatainak teljes bekerítését október 7-én csak Perczel késése akadályozta meg: a horvát csapatokat észak felöl Perczel, dél felöl a Csapó Vilmos vezette tolnai népfelkelés, keletről Görgey zárta körül. A magyar haderő a szabadságharc történetében az ozorai ütközetnél ejtett egyszerre legtöbb hadifoglyot, mintegy 9000 föt és felszerelésüket. Az ozorai diadalt követően Görgeyt honvédezredessé nevezték ki, és a Móga János tábornok vezette feldunai hadsereghez helyezték át, ahol az elővéd dandárparancsnoka lett. 
Októberben honvéd tábornokká (vezérörnaggyá) nevezték ki. A schwechati csatában a magyar hadak centrumának a parancsnoka volt. A schwechati csata során, 1848. október 30-án a Bécs melletti Schwechat falu közelében a Móga János vezette magyar sereg vereséget szenvedett a Windisch-Grätz vezette császári haderőtől. Előzőleg Windisch-Grätz rövid idő alatt a császári haderő jelentős részét átcsoportosította Bécs alá.

A várakozás ideje alatt így az erőviszonyok végérvényesen eltolódtak a császáriak javára. Október 23-ára Windisch-Grätz mintegy nyolcvanezer katonával és 210 löveggel rendelkezett, míg a magyar haderő létszáma nem érte el a harmincezer föt. A harcképességet tekintve a császáriak fölénye még ennél is nyomasztóbb volt. A csata során a jobb szárnyon a Guyon Richárd vezette dandár mintegy húsz perces küzdelem után szuronyrohammal bevette Mannswörth falut, a bal szárnyon pedig Répásy ezredes dandára késve vonult fel. Ez azt eredményezte, hogy a magyar hadrend ferde vonalat vett fel. Fennált a veszély, hogy az így kialakuló résbe benyomuló ellenség oldalba támadhatja a magyar centrumot, Móga ezért a Görgey Artúr vezette centrum visszavonulását rendelte el.

Felismerte a magyar bal szárny késése miatt kialakult helyzetet Jellasics is, mert utasította Franz Lichtenstein altábornagy lovashadosztályát, hogy kerüljön a magyar centrum hátába. Egyidejüleg Karl Zeisberg vezérőrnagy irányításával erős tüzérségi tűz alá vették Görgey csapatait. Görgey csapatainak nagy részét tapasztalatlan nemzetőrök és népfelkelők alkották, akik az ágyútűztől és a gyors visszavonulástól megijedtek, és tömegesen megfutottak. Görgey lovassággal fedezte a csapatok visszavonulását, és megmentette a lövegeket is.

A csatában szerzett és korábbi érdemei alapján Görgey Artúrt ismét tábornokká léptették elő, és kinevezték a feldunai hadsereg parancsnokává.

\subsection{A téli hadjárat}

Az 1848-49-es szabadságharc téli hadjárata során a hadművelet célja az volt, hogy Görgey elvonja az osztrák föerőt a Tisza vonalától a felvidéki bányavárosok felé, és egy megerősödött hadsereggel térjen vissza a küzdelembe. A kormány ekkor Debrecenben tartózkodott. A haditerv sarkpontja az a kérdés volt, vajon üldözik-e őt a császáriak vagy egyenesen Debrecen ellen vonulnak. 
Görgey felső-magyarországi hadművelete három részre osztható:

- Lipótvár felmentése,

- a bányavárosokba való kitérés és a hadtest egy hétig tartó pihentetése,

- végül menet a Szepességbe és innen Eperjes-Kassa környékére.

A Görgey Artúr tábornok parancsnoksága alatt álló Feldunai Hadtest a tél elején azt a parancsot kapta, hogy vonuljon vissza a Tisza vonala mögé, hogy onnan az összpontosított magyar forradalmi sereg központi támadással semmisíthesse meg az ország központját és fővárosát is birtokló osztrák császári hadat. Mivel 1848 decemberében az osztrákok már elfoglalták Budát, Görgey Komáromból a felvidéki bányavárosokon átvonulva tervezte meg a Tiszához való kijutást. A több oszlopban elörenyomuló honvéd seregtesteket szorosan követték császári üldözöik, kisebb-nagyobb csatározásokba is keveredve velük. Windisch-Grätz teljes erővel jóllehet csak két hétig követte, üldözését a cs. kir. mellékerőkre bízta, de ez az időnyereség lehetővé tette Perczel számára, hogy újjászervezze hadtestét. Míg a Görgey vezette fösereg több vesztes csata után, de mégis biztonságosan megérkezett Besztercebányára, addig a kimerült és pár napig Körmöcbányán erőt gyüjtő, Aulich Lajos ezredes által vezetett honvéd seregtestet körbevette és elszigetelte a túlerőben lévő ellenség. A rengeteg értékes hadianyagot, ágyúkat, tüzérségi muníciót szekereken szállító seregtest előtt a lehetséges utakat az erős tüzérséggel rendelkező, jól beásott császári sereg elállta. Görgeytöl, ill. Besztercebányától pedig a meredek s nagyobb tömeg vagy szekerek számára járhatatlan Körmöci-hegység választotta el öket. Ekkor merült fel egy Körmöci-hegységben húzódó, régi, beomlott bányászati alagút felhasználásának lehetősége. Az egykor sziklás gerince alá, egy olyan ponton, ahol az jelentős mértékben elkeskenyedik, korábban a bányászok egy 40 méter hosszú alagutat ástak. (Ezen át jutott el egykoron a besztercei oldalon kitermelt arany a körmöcbányai királyi pénzverdébe.) Az utász képzettséggel is rendelkező Görgey parancsára az Aulich-hadosztály két utászszázada egy nap megfeszített munkával újra kiásta, kiszélesítette és megfelelően alá is dúcolta a mindössze 2,5 m széles alagutat olyannyira, hogy azon 1849. január 24-én éjszaka az üldözői elöl menekülö teljes hadosztály átkelhetett. Az utászok heroikus teljesítményének hála, sikeresen kitörtek a bekerítésből, megmentették a tüzérséget, a társzekereken magukkal ho- 
zott készleteket, és egyesülni tudtak Görgey főseregével. Az alagút ma Görgey Artúr tábornok nevét viseli.

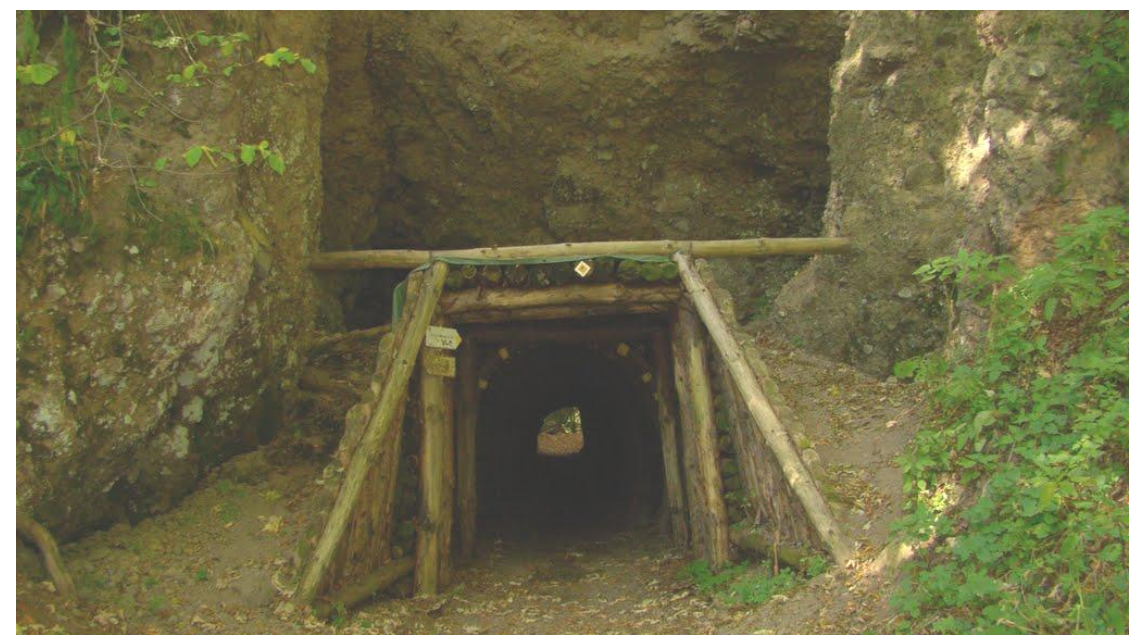

4. számú ábra. A „Görgey alagút”, amelyen keresztül magyar csapatok - az Aulich-hadosztály - erői vonultak át

Az osztrák parancsnokságnak eleinte fogalma sem volt arról, hogy a hadjárat során Görgey mit tervez (tartottak attól, hogy Bécs, illetve Olmütz felé fordul), ezért jelentős erőket hagytak Pest-Budán és környékén, valamint a morva határon. Mire kiismerték a haditervet, Görgey már időt nyert. Az üldözőkkel (Götz, Csorich, Jablonowski és Schlik), a folyamatos utóvédharcokat nem számítva háromszor bocsátkozott ütközetbe: Szélaknánál és Hodrusbányánál vereséget szenvedett, a Branyiszkói-hágónál Guyon Richárd csapatai viszont kierőszakolták az áttörést, ezzel szabaddá téve az átkelést Eperjes, illetve Kassa felé. Jóllehet Lipótvárat nem sikerült felmenteni, és a bányavárosokban sem tölthettek kellő időt, Görgey hadjárata stratégiai szempontból sikeres volt: az így nyert idő alatt sikerült megszilárdítania a Tisza melletti magyar ellenállás vonalát, a feldunai hadsereget pedig sikerült ütőképes egységgé kovácsolnia. Görgey serege Kassán egyesült a Klapka-vezette felső-tiszai hadsereggel. Görgey a téli hadjárat sikeréért megkapta a Magyar Katonai Érdemrend II. osztályát.

\subsection{A tavaszi hadjárat}

1849. március 30-án Kossuth (Vetter Antal betegsége idejére) ideiglenes fővezérré nevezte ki Görgeyt. Vezetésével április elején indult meg a támadó hadmúvelet. $A$ múveleti terv szerint ez a császári csapatok bekerítésére irányult, melyet átkaroló hadmüvelettel 
kívántak elérni. Létszámát tekintve Windisch-Grätz volt fölényben, de a manőverező jellegü magyar haditerv kiegyenlíthette a hátrányt. $A$ honvéd vezérkar - elsősorban Görgey Artúr és Klapka György által kidolgozott - terve az volt, hogy a magyar erők mintegy harmadrésze állásba megy Hatvan előtt, és várja az osztrák támadást, mintha ez lenne a fö hadsereg. Közben a többiek egy délnyugati kerülövel az osztrákok hátába kerülnek. A terv lényege az volt, hogy a VII., a legerősebb hadtest Hatvannál állva magára vonja a császári-királyi fővezér figyelmét, míg három másik hadtest (I., II., III.) igyekszik az ellenséges fősereg hátába kerülni, és elvágni azt a fővárostól. A terv igen kockázatos volt. Ha Windisch-Grätz rájön, hogy Hatvannál nem az egész magyar hadsereg áll, s szétveri a VII. hadtestet, könnyen ő kerülhet a magyar főerők hátába, és elvághatja őket hadműveleti bázisuktól. A bekerítés egy elterelő hadmüvelet sikerességétől függött, melyet a VII. hadtestnek a fösereg látszatát keltve Hatvan környékén kellett végrehajtania. Eközben az I., II. és III. hadtesteknek kellett a Jászságon át megkerülnie az ellenséges sereget. A terv szerint a négy hadtestnek április 7-én egyesült támadást kellett intéznie a császári csapatok ellen, és siker esetén a főerőket elvágták volna Pesttől.

Az első összeütközésre a császári csapatokkal Hatvannál (1849. április 2.) került sor, amikor a gyöngyösi országúton menetelö VII. hadtest keveredett kisebb csatározásba Schlik felderítő elővédjével. Április 2-án a VII. hadtest megindult Hort és Hatvan felé. A Hatvanból előnyomuló osztrák Schlik-hadtest élén a Parrot-dandár haladt, amelyet Schlik arra utasított, hogy nyomuljon elöre Hort ellen, és kényszerítse a magyarokat erejük felfedésére. Parrot csapatai délután 1 óra tájban azonban beleütköztek Gáspár és Poeltenberg csatarendben lévő hadosztályaiba. Erre Schlik utasította a Künigl- és Fiedlergyalogdandárt, valamint a Montenuovo-lovasdandárt, hogy támadjanak. Az ütközet délután három óráig nagyobb részt ágyúzásra korlátozódott: Gáspár várta, hogy a hadtestböl Ecsedre kikülönített két lovasszázad és a Csányba kikülönített Liptay-dandár megérkezzenek, Schlik csapatai pedig képtelenek voltak tért nyerni. Délután 2-kor Poeltenberg azt jelentette Görgeynek, hogy a csapatok felállítása változatlan, és hogy a Liptay-dandár beérkezése után megtámadja a szőlőhegyeket. Délután 3 órára megérkeztek a VII. hadtest kikülönített csapatai, és megérkezett a parancs az ellenség megtámadására. Erre Gáspár a Poeltenberg-hadosztályból a Kossuth- és Zámbellydandárt az ellenség balszárnyának átkarolására küldte. Ide utasította a Liptay-dandárt is. A Zámbelly Lajos alezredes vezette két löveg és egy lovasszázad oldalba fogta az ellenséges balszárnyat, a Liptay- 
dandár pedig a jobbszárnyon nyomult elöre. Ezalatt a Gáspárhadosztály a hort-hatvani úton foglalt állást, nem mozdulva sem előre, sem hátra, hogy időt adjon Poeltenbergnek az átkarolás végrehajtására. Schlik visszavonult a Hatvan és Hort közötti szőlőhegyekre, de a Liptay-dandár és a Poeltenberg-hadosztály többi csapatai ide is követték, és megkezdték a Hatvan elleni koncentrikus előnyomulást. Schlik erre a Zagyva-híd előtti magaslatokra vonta vissza tüzérsége és gyalogsága egy részét, utászaival egy hadihidat veretett a Zagyván, majd megkezdte Hatvan kiürítését. Döntésébe az is közrejátszott, hogy Damjanich III. hadtestéből a Wysocki-hadosztály is Gáspár segítségére sietett, és Schlik észrevette a közeledő hadoszlopot. A visszavonulást a Zagyva-hidat védő cs. kir. gyalogság fedezte, és mindkét hidat sikerült lebontania. Mire a Wysocki-hadosztály megérkezett, Schlik feladta Hatvant, és lovasságával Bag és Hatvan közé, gyalogságával és tüzérségével Aszódra, majd Gödöllőre vonult viszsza. Az ütközet magyar győzelemmel ért véget, Schlik csapatait Hatvan mögé sikerült szorítania Gáspár és Poeltenberg csapatainak. Az osztrák veszteség mintegy 200 fő volt, míg a magyar elérte a 150 föt. ${ }^{23} \mathrm{~A}$ hort-hatvani csata legföbb eredményeképpen a VII. hadtest biztosítani tudta a Zagyva-vonal ellenőrzését.

Április 4-én, a Klapka-vezette I. hadtest 11000 katonával és 40 löveggel Tápióbicskénél előzetes felderítés nélkül vonult be a faluba. A császári sereg Jellasics hadteste 18000 emberrel és 40 löveggel a Tápió túloldalán, Tápióbicskén éjszakázott. Az osztrák hadtest éldandárjának elvonulását követően Tápióbicskére bevonult a hadtest két utóvéd dandárja. A hadtestparancsnok nem ellenőrizte a hírt a Jellasics-féle kiürítésröl, és abban a meggyőződésben nyomult Tápióbicske felé, hogy nincs a faluban ellenség. Ott tartózkodott a Jellasics hadtestéből származó egész Rastics-dandár. Habár az osztrákokat is meglepte a magyar csapatok hirtelen feltūnése, ellentámadásukkal kavarodást és nagy veszteséget okoztak Klapka csapatainak, amelyek a faluból visszavonultak a Tápió hídjához. A honvédek szervezetten indult visszavonulása csakhamar fejvesztett menekülésbe csapott, és a pánik magával ragadta a Nagykáta felöl közeledő hadtest zömét is, mely menekülés közben a Tápió hídján összetorlódott. Klapka négy lovasszázadot küldött a csapatok fedezésére, ezek nagy veszteségek árán megállították a császáriakat, annak dacára, hogy segítette őket a horvát báni huszárezred. Huszárjaink visszaverték a horvátokat, bár hamarosan az ellenség ágyútüzébe kerültek, és kény-

23 Liptai Ervin (szerk.): Magyarország hadtörténete Zrínyi Kiadó, Budapest, 1985 I. köt. 509. o. 
telen voltak visszafordulni. A nyomukban előretörő két császári dandár kijutott a Tápió hídjához, és a folyóval párhuzamos dombokon előnyös hadállást vett fel. Ráadásul több ágyút és lőszerkocsit zsákmányoltak, és 123 honvédet ejtettek foglyul. Később a folyó Nagykáta felöli oldalán Klapka rendezte csapatait. A csata menetét az érkező Damjanich tábornok III. hadteste fordította meg. Délután fél kettőkor ugyanis megérkezett a csatatérre Damjanich a 3. hadtesttel, 11000 emberrel és 40 löveggel. A helyszínre érkezett Görgey fövezér is, aki személyes jelenlétével állította meg a fejvesztett visszavonulást, és azonnali támadásra adott parancsot. Damjanich az arcvonalban leváltva Klapka csapatait szervezte meg a támadást. A híd két felén felállított magyar ütegek pontos lövéseikkel hamarosan távozásra kényszerítették a túlparti osztrák tüzérséget. Görgey a reménytelennek tűnő helyzetben kérte a katonákat, hogy mentsék meg a magyar fegyverek becsületét. Elsőként a 9. zászlóalj támadott Kiss Pál alezredes parancsnoksága alatt a Tápió hídjának elfoglalására. $A z$ első rohamban a hídra vezető keskeny ösvényen összetorlódott zászlóalj jelentős veszteségeket szenvedett. A visszavonulásuk után Damjanich a 3 . zászlóaljat vetette be a híd elfoglalására. Miután a hidat önfeláldozó rohamokkal elfoglalták, a magyar támadás folytatódott a homokbuckák közt. Az osztrákok ezen a napon utoljára ellentámadást indítottak, hatására a honvédség lassan kezdett visszahúzódni. Időközben megérkezett két ágyú, így a kartácstűzzel és a szuronyrohammal a magyar csapatok az előttük álló dombsort hamarosan megtisztították az ellenségtől. További erősítések bevetését követően a magyar szuronyrohamok elöl a két ellenséges dandár Tápióbicskén túlra menekült. Damjanich hadteste így kivívta a győzelmet. A Tápiószecső irányába visszavonuló osztrákok üldözését a lovasság - két huszárezred - folytatta a délutáni órákig. A magyar győzelemmel végződött csata súlyos veszteségeket okozott a magyaroknak is, csaknem 800 fő volt az elesettek száma, Klapka hadteste 4 löveget vesztett. A csatát vesztett császáriaknak 400 halottjuk volt.

Az 1849. április 6-án megvívott Isaszegi csata a tavaszi hadjárat döntő ütközete volt, melynek során Görgey tábornok döntő győzelmet aratott a császári sereg felett. Az Isaszeg és Gödöllö között felvonuló, Windisch-Grätz tábornok vezette császári-királyi sereg 55000 főt számlált, tüzérsége 214 lövegből és röppentyűből állt. A Görgey Artúr vezette magyar fösereg összlétszáma viszont csak 47 500 fő körül volt. A magyar tüzérséget mindössze 198 löveg alkotta, ám az osztrákokéhoz hasonló lovagló tüzérséggel csak alig rendelkezett. Az osztrák csapatok jelentős nehézlovassági kötelékkel rendelkeztek, ilyen csatadöntő csapatnemmel a magyar fél szintén nem 
rendelkezett. De a magyar csapatok nem rendelkeztek huzagolt fegyverekkel felszerelt vadászszázadokkal sem. Az erőviszonyokat, a csapatok felszereltségét és kiképzettségét tekintve tehát egyaránt az osztrák fél volt előnyben. A csapatokat azonban két magasan képzett tiszt, Görgey és Klapka vezette. Az ő együttmüködésük vezetett el azután a magyar győzelemhez.

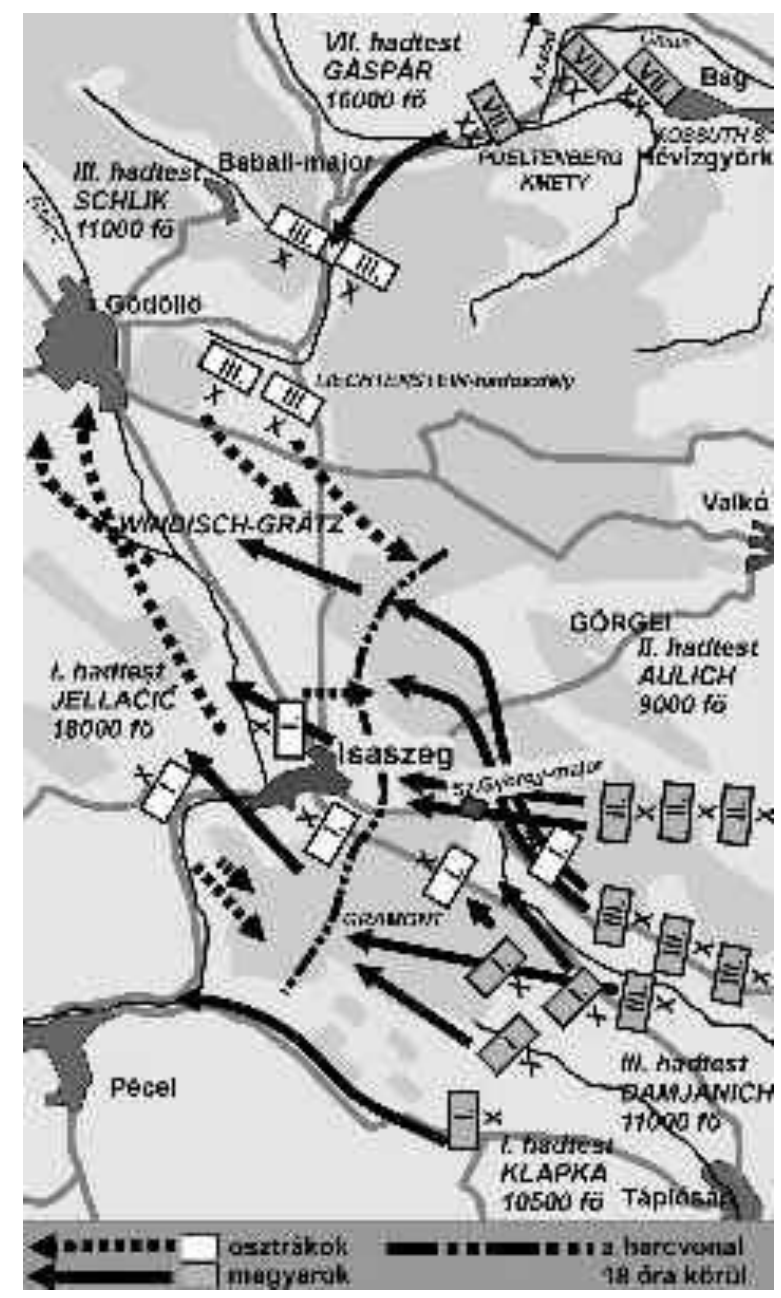

5. számú ábra. Az isaszegi csata, Görgey első önállóan vezetett ütközete, amely döntő magyar győzelemmel zárult

A csata során Gáspár András VII. hadteste fél 1 körül érte el a Galga vonalát Aszódnál, s megszállta Turát és Bagot. A Kmetyhadosztály Hévízgyörk és Bag között Schlik lovasságába ütközött, de ez harc nélkül visszavonult Gödöllőig. Ezután a hadtest csapatai aznap már semmilyen aktivitást nem mutattak, Gáspár úgy vélte, hogy eleget tett aznapi feladatának. Nagyjából ezzel egy időben Damjanich 
III. és Klapka I. hadteste is elérte az Isaszeg előtti Király-erdő keleti szegélyét. Damjanich csapatai megtámadták Jellačić utóvéd dandárát, amely az erdőn át Isaszegre vonult vissza, s maga mögött több helyen felgyújtotta az erdőt. Ezután Klapka csapatai támadták meg Franz Adam Grammont von Linthal vezérörnagy dandárát, s üzték vissza Isaszeg felé. A magyar támadást Zákó István őrnagy dandára hajtotta végre. Bobich János alezredes dandárának csatárláncba osztott 28. zászlóaljával átkergette a Király-erdőből az ellenséget, és betört Isaszegre. A falunál azonban már érvényesült az ellenség fölénye. Jelačić három gyalog-és egy lovasdandárának Zákó nem tudott ellenállni, és nemcsak Isaszeget kellett kiürítenie, hanem - súlyos veszteségeket szenvedve - a Király-erdőbe vonult vissza. Eközben a két zászlóalj beleütközött Bobich felfejlődőben lévő dandárába. A 28. zászlóalj kötelékei felbomlottak, és így teljesen védtelenül érte a csapatot a császári-királyi vérteslovasság támadása. A zászlóalj pillanatok alatt súlyos veszteségeket szenvedett. Szerencsére a mögötte haladó vasi 44 . és a zalai 47 . zászlóalj már jobban állta a sarat. A zalaiak sortüzet zúdítottak az ellenséges lovasságra, mire az felhagyott az üldözéssel. A vérteseket azután oldalba kapta a Bátori-Sulcz Bódog örnagy vezette dandár is. Ezt követően a zalaiak megrohanták az erdőbe benyomult császári-királyi vadászokat, és kiűzték őket. Alighogy a némileg rendezett Bobich-dandár elérte az erdő szélét, az Isaszeg melletti magaslatokon álló horvát határörök lőni kezdték azt. A magyar csapatok, akárcsak Sulcz dandára, nem tudtak kijutni a sürüből. Délután 2 óra tájban Damjanich csapatai is elérték a Király-erdő nyugati szegélyét. Damjanich rögtön látta Klapka csapatainak veszélyeztetett helyzetét. Knezić Károly ezredes egyik dandárát a Király-erdő északi kiszögelléséhez irányította. Egy másikat Kiss Pál alezredes vezetésével Klapka megsegítésére küldte. Tüzérségét egy kopasz dombon állította fel, lovasságát pedig Isaszegtől keletre, a Király-erdő egyik hajlatában. Ugyanakkor Aulich Lajos tábornokot is a csatatérre küldte a II. hadtesttel. Damjanich támadni akart, hogy Klapkát tehermentesítse. Mielőtt azonban Kiss dandára megérkezhetett volna, Klapka visszavonult. Damjanich ezután eddig elfoglalt állásának tartására szoritkozott. Amikor három óra tájban észrevette, hogy a Klapkát üldöző császári-királyi csapatok visszavonulnak az Isaszeg melletti magaslatokra, támadásba lendült. A Zákóés Bobich-dandárok az ellenség lövései elöl visszavonultak. Damjanich támadása nem járt sikerrel. Windisch-Grätz felismerte, hogy Gödöllőnél nem kell tartania Gáspár újabb támadásától, ezért Schlik egyik hadosztályát Isaszeg felé indította, amely oldalba támadta az Isaszeg ellen nyomuló Damjanichot. A magyar hadtestparancsnoknak vissza kellett vonulnia a Király-erdőbe. 
A magyar csapatok eddig egymástól függetlenül harcoltak: Klapka, Damjanich, Gáspár és Aulich a saját feje után ment. Görgey ugyanis valamivel elörébb, Kókán tartózkodott. Délután 3 óra tájban Görgey lóra ült, majd sietve a csatatérre indult. A II. hadtest (Aulich) csapatai ekkor a csatatér felé tartottak. Görgey találkozott is velük a Király-erdő keleti szélén. Klapka visszavonulása miatt a Király-erdő szélének egy része megszállatlanul maradt. Ez pedig azzal a veszéllyel fenyegetett, hogy az ellenség betör a résbe, és elvágja egymástól a magyar csapatokat. Görgey tehát a II. hadtest négy zászlóalját a jobbszárny felé, kettőt a veszélyeztetett hadközépre, a 61. honvédzászlóaljat pedig Klapka megsegítésére küldte.

Görgey ezután Klapka csapatait kereste fel. Megjelenése lelkesítette a katonákat. Amikor Görgey előbbre vágtatott, csakhamar Klapkára bukkant, aki ekkor már reményvesztetten vezette vissza csapatait az erdő belsejébe. Klapka ezt a döntését azzal indokolta Görgey előtt - utóbbinak emlékiratai szerint -, „hogy gyalogsága már ki van merülve $s$ teljesen ellődőzte töltényeit, jobb lesz tehát ma nem erőltetni tovább a dolgot; holnap talán inkább sikerülhet, ami ma már ki nem vihető.” Erre Görgey hevesen azt válaszolta: „Nekünk itt ma győznünk kell, vagy újból visszakuporodni a Tisza mocsarai mögé! Ha a gyalogságnak nincs tölténye, van szuronya! Elöre!"24 Görgey ezzel egy veszteségterhes támadás megindításának felelősségét vállalta magára. Döntése azonban - tekintet nélkül a leharcolt Klapka-dandár e támadás során bekövetkezett veszteségeire - az isaszegi csata győztes kimeneteléhez vezetett el.

Görgey ezután a jobbszárnyra sietett. Közölte Damjanichcsal új haditervét, és azt, hogy Klapka ismét elörenyomul. Schlik hadosztálya közben egyre eröteljesebben rohamozta Damjanich csapatait. Az Aulich által Damjanich segítségére küldött négy zászlóalj is megérkezett. Damjanichnak immár tíz zászlóalja volt szemben Schlik öt zászlóaljával. Ugyanakkor tizenhét lovasszázadával ellensúlyoznia kellett a harmincnégy lovasszázadból álló ellenséges lovasságot; lövegei száma pedig feleakkora volt, mint Schlik ágyúié. A jobb szárnyon este 11 óráig változatlan maradt a két fél helyzete.

A balszárnyon Klapka és Aulich csapatai este 7 óra tájban lendültek támadásba. Előbb Isaszeget vették be, majd az égő falun át

24 Banlaky-banlaky-jozsef-a-magyar-nemzet-hadtortenelme-2/21-magyarorszag184849-evi-fuggetlensegi-harcanak-katonai-tortenete-5B2E/iv-a-tavaszihadjarat-a-magyar-tamado-hadjarat-634B/huszonkettedik-fejezet-64EF/azisaszegi-csata-1849-aprilis-6-an-6568/ 
megrohanták a Rákos-patak jobbpartján lévő ellenséges állásokat, és onnan is elüzték a császári-királyi csapatokat. Windisch-Grätz 9 órakor kénytelen volt visszavonulni. A magyar jobbszárnyon a késő esti órákig döntetlen volt a harc. Középen, ahol a II. hadtest csapatainak egy része és a III. hadtest lovassága harcolt, szintén nem volt döntő összecsapás, a balszárnyon azonban Jellačić csapatai Gödöllő felé vonultak vissza. Az osztrákok 4000 halottal és sebesülttel menekültek Pest irányába.

Ezt a jelentős léptékű győzelmet követően nem maradt más hátra, mint az ellenfél erőinek üldözése. Isaszeget követően Görgey tábornok Vácnál (április 10.) és Nagysallónál (április 19.) sorozatos csapásokat mért a császári föseregre. Április 26-án felmentette Komáromot az ostromzár alól. Május 21-én, 17 napos ostrom után bevette Buda várát. 1849. május 27-én Görgeyt kinevezték altábornaggyá. Egyúttal megkapta a Magyar Katonai Érdemrend I. osztályát is. Szintén még májusban megválasztották a dédesi kerület országgyülési képviselőjévé.

\subsection{A nyári hadjárat}

A június 26-i pesti minisztertanácsi ülésen keresztülvitte haditervét, mely szerint a további hadmüveleteket kifejezetten az osztrákok ellen kell irányítani Komárom térségéböl, míg az oroszokkal való nyílt ütközetet lehetöleg kerülje a magyar hadsereg: kísérelje meg az orosz hadsereget tárgyalásokkal kivonni a háborúból.

Haynau ellentámadása a győri csata (június 28.) után Komárom falai alá szorította vissza seregét. Ennek hatására Kossuth elvetette Görgey tervét, és egy újabb, Görgey távollétében tartott minisztertanácsi ülésen a Szegednél történő összpontosítás mellett döntött. Görgey helytelenítette ezt a megoldást, de az engedelmességet ezúttal sem tagadta meg.

A július 2-án Komárom mellett vívott csatában egy huszárroham élén súlyos fejsebesülést szenvedett, ezért a hadsereg vezetését ideiglenesen (július 2-11.) Klapka Györgynek adta át.

Július 5-én a minisztertanács újra Görgeyre ruházta a hadseregparancsnok tisztét. Július 6-án a Komáromban tartott haditanács elfogadta Görgey tervét, hogy július 9-én kíséreljék meg az áttörést. Július 11-én vívták a második komáromi csatát (Klapka György vezetésével). Kossuth többszöri sürgetésére Görgey július 13-án elhagyta 
Komáromot, hogy a magyar seregtestek gyülekezőhelyéül kijelölt Szeged-Maros vonal felé vonuljon. Vácnál azonban már cári csapatok állták útját. Véres utóvédharcokkal (július 15., 17., 23., 25-26., 28.), nagyjából a téli hadjárat útvonalát megismételve Tokajig vonult, ezalatt sikerült az orosz főerőket távol tartania a tiszai és a déli magyar seregtől. Ezután az oroszokat megelőzve átkelt a Tiszán, Nyíregyháza érintésével vonult tovább Nagyvárad felé. Eközben Debrecennél, augusztus 2-án oldalvédjének parancsnoka, Nagysándor József vigyázatlanul bevárta az orosz főhadsereget, és a kibontakozó egyenlőtlen csatában vereséget szenvedett, súlyos veszteségekkel csatlakozott Görgey főseregéhez. Nagyváradról augusztus 5-én Aradra hívták Görgeyt, hogy serege ott egyesülhessen a Dembińskivezette magyar déli hadsereggel. Görgey eröltetett menettel érkezett augusztus 9-10-én Aradra. A remélt seregösszevonás elmaradt, mert Henryk Dembiński altábornagy végül Temesvár felé vezette a magyar déli hadsereget. Így Görgey és serege a Temesvár mellett lezajlott döntő ütközetben nem vehetett részt.

A temesvári vereség (augusztus 9.) után, augusztus 10-én este Arad várában Kossuth négyszemközti tanácskozást tartott Görgeyvel. Még várták a jelentést a temesvári csata kimeneteléröl. Vereség esetére Görgey kijelentette a kormányzónak, hogy leteszi a fegyvert. Kossuth éjszaka megjegyzés nélkül továbbküldte Görgeynek a katasztrofális vereségről szóló hadijelentést. Ezután a kormány felhatalmazta Görgeyt az orosz föhadsereggel való külön tárgyalásra. Görgey felszólítására 1849. augusztus 11-én a magyar kormány lemondott, és ráruházta a katonai és a polgári teljhatalmat. Ez jogi hátteret biztosított, így Görgey a fegyverletételhez törvényes úton foghatott hozzá. 1849. augusztus 13-án a magyar fösereg - 29889 fő 144 löveggel - Világos mellett feltétel nélkül letette a fegyvert az orosz hadsereg képviselője (Rüdiger orosz lovassági tábornok) előtt. Görgeyt másnap elválasztották tábornoktársaitól, és Nagyváradra vitték. A nagyváradi orosz hadifogságban augusztus 27-én értesítették, hogy a bécsi udvar kegyelmet adott neki, azonban ausztriai számüzetésre ítélte.

\section{Források}

Ács Tibor: Hadi tanfolyam a Bölcsészeti Karon és a Pesti Egyetemi Légió 1848-1849 - Fejezetek az Eötvös Loránd Tudományegyetem történetéböl 22. Budapest, 2001.

Antall József: Egy évszázados per, A Görgey-kérdés tegnap és ma, Orvostörténeti Közlemények 158-165., Budapest 1997-1998. 
Banlaky-banlaky-jozsef-a-magyar-nemzet-hadtortenelme-2/21magyarorszag-184849-evi-fuggetlensegi-harcanak-katonai-tortenete5B2E/iv-a-tavaszi-hadjarat-a-magyar-tamado-hadjarat634B/huszonkettedik-fejezet-64EF/az-isaszegi-csata-1849-aprilis-6an-6568/

Dr. Gáspár Tibor: A fegyver- és löszerbiztosítás hazai történetének fontosabb tanulságai. PhD értekezés. ZMNE, 2008.

Dr. Miskolczy István- Dr. Mezősi Károly: Egyetemes történelem II. kötet. Szent István Társulat, Budapest, 1939.

Feith László: A magyar Napóleon - A szabadságharc hadvezére. https://honvedelem.hu/cikk/108874 a magyar napoleon (2018. február 28.)

Glatz Ferenc Egy vödör víz, avagy találkozásaim az árulókkal. História 1985. évi 1. szám

Görgey Artúr (Demár János álnéven): Dembinszki emlékiratai I. - V. rész. Budapesti Szemle, 1875.

Görgey Artúr halotti kivonat. Budapesti Központi Királyi Járásbíróság iratai. Peres és peren kívüli iratok. Ügytípus: hagyatéki ügy. Évszám: 1916. Ügyszám: 183834. Görgey Artúr görgői és toporczi. Születési hely: Toporc. Születési idő: 1818. Elhalálozás ideje: 1916.05.21. Státus/foglalkozás: honvéd tábornok. Vallás: evang. Lakhely: Budapest V. Mária Valéria u. 17. Kiemelt irattípusok: Végrendelet, Hagyatéki leltár, Halálesetfelvétel.

Görgey Artúr: A honvédsereg egyenruhájáról. Budapest, 1848. június 5. In.: Hermann Róbert (szerk.): Görgei Artúr válogatott írásai. Zrínyi Kiadó, Budapest, 2018. 67. o.

Görgey Artúr: Életem és működésem Magyarországon 1848-ban és 1849-ben. Európa, Budapest 1988.

Hermann Róbert (szerk.): Görgei Artúr válogatott írásai. Zrínyi Kiadó, Budapest, 2018.

Hermann Róbert (szerk.): Kossuth Lajos és Görgey Artúr levelezése, 1848-1849. Budapest, 2001. In: Millenniumi Magyar Történelem. Források. 73-74. 0.

Hermann Róbert Görgey Artúr élete Magyar idők, 2016.03.15.

Hermann Róbert: 1848-1849. A magyar szabadságharc hadtörténete. Budapest, 2001. 
Hermann Róbert: Aggházy Kamil visszaemlékezése Görgei Artúrra. A Hadtörténeti Múzeum Értesítője 16. szám

Hermann Róbert: Görgei Artúr, a hadvezér. Hadtörténelmi közlemények, 1999. évi 112. évf. 1. sz.

Hermann Róbert: Görgey Artúr élete. Magyar idők, 2016.03.15.

Hermann Róbert: Görgey Artúr. Rubicon, 2018. évi 1. szám

Interjú Dr. Hegedűs Ernő mk. őrnaggyal Görgey Artúrról a Hadtörténeti Intézet és Múzeumban. In.: Görgey Gábor - Dr. Hermann Róbert - Dr. Katona Csaba - Dr. Hegedűs Ernő: Görgey Artúr. Magyar Krónika, 18/25. adás 2018. 06. 23., 26 perc. MédiaKlikk. https://www.mediaklikk.hu/video/magyar-kronika-1825-adas-gorgei-artur/

(03'05-04'11.; 06'40-09'02.; 09'40-10'20.; 13'15-13'48.; 21'2323'25.)

Interjú Katona Tamással. In.: Görgey: egy mítosz vége. http://hvg.hu/velemeny/20090315 gorgey arulo

Konek F.: Görgey Arthur chemiai munkássága, Természettudományi Közlöny, XLVIII 1916 és Chemiker-Zeitung 40, 1916.

Kosáry Domokos: A Görgey-kérdés 1945 után címü elöadása 1993. jan. 28-án a Hadtörténeti Intézetben

Kosáry Domokos: A Görgey-kérdés és története. Egyetemi Nyomda, Budapest 1936.

Liptai Ervin (szerk.): Magyarország hadtörténete Zrínyi Kiadó, Budapest, 1985 l. köt.

MOL 12101212 raktári szám, 420. XII. Hadügyi vonatkozású irattárak és iratok.

Móra László: Görgey Artúr mint kémikus és haditechnikus. Technikatörténeti szemle, 20. évf. 1993.

Móra László: Katonai sikereit elősegítették kémiai tanulmányai - 175 éve született Görgey Artúr. Magyar Tudomány, 1993. évi VIII. évfolyam 11. szám 2004. november.

Múltbanézés XIV/10 - Bekerítve - Görgey ürügyén 1949. október 13. https://www.youtube.com/watch?v=ZukBqVG9idQ

Múltbanézés XIV/6b - A Honvéd (1946-1949)

https://www.youtube.com/watch?v=h1F6K9E4_gc

Múltbanézés XIV/6b - A Honvéd (1946-1949)

https://www.youtube.com/watch?v=h1F6K9E4_gc 
Perjés Géza: Az élelemellátás kérdése Napóleon oroszországi hadjáratában. Századok, 1963.

Perjés Géza: Hadseregélelmezés, logisztika és stratégia a vasutak elterjedése előtti kétszáz esztendőben. Hadtörténelmi Közlemények, 1963. 1. sz.

Perjés Géza: Kossuth és Görgey konfliktusa. Hadtörténelmi közlemények, 2004. (117. évf.), 2. sz.

Pethő Sándor - Julier Ferenc: Görgey Artúr. Budapest, é. n.

Pünkösti Árpád: Rákosi a csúcson 1948-1953. Európa Kiadó, Budapest, 1996.

Sólyom László előadása „A szabadságharc bukásának okai” címmel 1949 október 14-én a Magyar Történelmi Társulatnál

Sólyom László: A váci nyilatkozat. Honvéd katonai folyóirat, 1948. 3. évf. 8-9 szám, 36-49. o.

Szabadváry Ferenc: Katonatisztből kémikus, kémikusból hadvezér: Görgey Artúr. Bp., I. 20., Magyar Kémikusok Egyesülete

Than Károly: Egy magyar hadvezér mint chemikus. Budapesti Szemle 1893. évi 3. sz. Vol. 74. No. 197. pp. 161.

Új Magyar Lexikon, 1-6. kötet + Kiegészítő kötet. Akadémiai Kiadó, Budapest, 1962-1980.

Vámos Éva Katalin: Természettudósok három generációja Magyarországon, 1849-1918 Technikatörténeti szemle 2005. évi 6. sz. 27. évf.

Varga János: Az áruló. Történelmi Szemle, 1964. 596-613. 0. 